\section{Heritability and Patterns of Inheritance of the Ripening Date of Apples}

\author{
Stephen J. Tancred and Aldo G. Zeppa \\ Department of Primary Industries, Granite Belt Horticultural Research Station, \\ P.O. Box 501, Stanthorpe Q4380, Australia
}

\author{
Mark Cooper \\ Department of Agriculture, The University of Queensland, Brisbane Q4072, \\ Australia
}

\author{
Joanne K. Stringer \\ Bureau of Sugar Experimental Stations, P.O Box 86, Indooroopilly Q4068, \\ Australia
}

Additional index words. Malus domestica, apple breeding, heritability, combining ability

\begin{abstract}
A major objective of the apple (Malus domestica Borkh.) breeding program in Stanthorpe, Australia, is to develop early ripening, high-quality cultivars. The heritability and inheritance of ripening date was investigated. Regression of offspring on midparent harvest dates and estimation of best linear unbiased predictions for parents were used to demonstrate that apple harvest date is highly heritable. Predominantly, additive genetic components of variance are responsible for the variation. Despite the existence of some specific combining ability variance and some non-normal family distributions, the best strategy for a breeder to predict the harvest date of progeny is to calculate the mean harvest date of parents.
\end{abstract}

Apple breeding is a long-term and costly process due to the long juvenility period and the large size of mature apple trees. However, because apples are vegetatively propagated, a selected cultivar is genetically fixed and can have industry use for hundreds of years (Brown, 1975).

Stanthorpe is Australia's earliest apple production district, and a breeding program was initiated to enhance this market advantage. The Queensland Dept. of Primary Industries began apple breeding at Stanthorpe in 1964 to produce new red dessert cultivars that matured before 'Jonathan', the standard early cultivar, and that were of a higher quality than the commercially available early cultivars. Because the eating quality of early season apples is often inferior to that of mid- and late-season apples, the breeding plan had the two parallel objectives of earliness and high eating quality. Three cultivars that mature before 'Jonathan' have been released from the Stanthorpe program: 'Earlidel', 'Summerdel', and 'GB 6343' (Tancred et al., 1994).

Because quantitative studies of fruit genetics have usually been done retrospectively from breeding program data, they often lack a specific design for estimation of heritability.

Received for publication 12 July 1994 . Accepted for publication 7 Dec. 1995. We thank Susan K. Brown for reviewing the manuscript and Halina Kruger and Chandra Smith for their help with data entry. The cost of publishing this paper was defrayed in part by the payment of page charges. Under postal regulations, this paper therefore must be hereby marked advertisement solely to indicate this fact.
This, too, is the case for the Stanthorpe program. However, genetic parameters have been usefully estimated in this manner for several tree fruit crops (Abe et al., 1993; Dicenta et al., 1993; Hansche et al., 1966, 1972a, 1972b; Thompson and Baker, 1993), and we adopt a similar strategy.

Only a few studies have been made of apple ripening date, and they all concluded it showed polygenetic inheritance. Crane and Lawrence (1933) observed that no sharply discontinuous variation occurred and that the majority of progeny ripened between the parents. Howlett and Gourley (1946), Bishop (1951), and Davis et al. (1954) concurred with this finding, but Hartman and Howlett (1942) found transgressive segregation with a considerable percentage of progenies earlier than the early parent and some later than the late parent. Brown (1960) found the progeny mean on average 2 weeks earlier than the midparent value, except for crosses involving very late parents, where the progeny mean was up to 2 months earlier than the midparent mean. Brown (1975) reviewed the breeding and genetics of apples and Brown (1992) has reviewed the inheritance of Mendelian traits in apples. Way et al. (1990) have described Malus spp. genetic diversity.

Breeders at Stanthorpe hoped that by hybridizing early ripening parents with highfruit-quality parents, families would be generated that had a sufficient number of seedlings that matured before 'Jonathan', to enable selection to be made within these on fruit quality characters. This study reports the variation in ripening date within and among families pro- duced in the Stanthorpe apple breeding program. Several quantitative methods that can be used as predictive selection tools are used. Fruit quality data will not be discussed here.

\section{Materials and Methods}

Parent cultivars and hybridizations. Biparental hybridizations were done among 13 early, mid-, or late-maturing apple cultivars from 1964 to 1970 . The parents were selected from the best available in Australia at the time (Table 1). Two of the cultivars are full-sibs ('Milton' and 'Early McIntosh'), but no genetic relationship is known to exist between any of the others. Thirty-six families were produced with an average size of 286 individual trees (range 16 to 1100 ). The seedlings were field-planted between 1966 and 1971. Only two sets of reciprocal crosses were made, 'Milton' X 'Early McIntosh' and 'Golden Delicious' $x$ 'Jonathan'.

Planting design. Because the primary aim was to select suitable cultivars for commercial use, there was no planned trial layout or replication for the purposes of this study. Trees within a family were planted beside each other in orchard rows each year. However, because several crosses were made over a number of years, complete families were not always planted together.

Population management. Seedlings were evaluated for ripening date every 2 to 5 days during the harvest period. Ripening date was determined by subjective assessment of fruit texture, flavor, blush color, and background color. Seedlings were culled or further propagated after several years of consistent performance. Seedling trees were observed cropping for 3 years, on average. About $16 \%$ of the seedlings planted never cropped and were disregarded in all calculations. Observations were made from 1973 to 1985 , when the orchard was removed.

Seasonal adjustments. Due to weather variation between years, the harvest date for any particular genotype may vary from year to year. These year effects were considered to be fixed effects in the analyses. To account for these effects, each year was assigned an earliness or lateness factor from the harvest dates of standard cultivars on the research station and on district farms. This factor ranged from

Table 1. Ripening date of 13 apple cultivars used as parents at Stanthorpe, Australia. Ripening date expressed as day relative to 'Jonathan'.

\begin{tabular}{lc}
\hline \hline Parental cultivar & Ripening date \\
\hline Stark's Earliest & -45 \\
Milton & -43 \\
Early McIntosh & -37 \\
Canterbury & -36 \\
Ruby Gem & -34 \\
Carrington Red & -33 \\
William's Favourite & -30 \\
Earliblaze & -26 \\
Jonathan & 0 \\
Sayers & 7 \\
Delicious & 10 \\
Golden Delicious & 22 \\
Granny Smith & 47 \\
\hline
\end{tabular}


14 days early to 14 days late. For the 13 years of observation, it averaged 1.3 days early. Harvest dates of individual progeny within families were adjusted by this factor for each year. Harvest dates for each tree were then averaged across years. All harvest dates are expressed relative to that of 'Jonathan'.

Genetic analysis. The parents used spanned a wide range of maturity periods (Table 1 ) and were considered to constitute a random sample from the base population accessed by the Stanthorpe breeding program. Narrow-sense heritability $\left(\mathrm{h}^{2}\right)$ was estimated using the linear regression of year-adjusted offspring performance on the average performance of their parents, or midparent value (Falconer, 1989). Three procedures for estimating offspring midparent regression were investigated following Kempthorne and Tandon (1953) and Bohern et al. (1961): 1) the regression of the phenotypic mean of all offspring from a given biparental combination on the midparent value; 2) the regression of offspring on midparent, in which the midparent values were repeated for each of the progeny; and 3) the weighted regression technique of Kempthorne and Tandon (1953). As have been found by others, the results of each procedure were similar, and only the first procedure, the regression of the phenotypic mean of all offspring on the midparent value, is presented.

The assumption that the effects of environment are randomly distributed among the individuals, so that the environmental correlation between individuals in a progeny group is zero (Bohern et al., 1961), is unlikely to be fulfilled. However, since all progeny from a cross were not grown adjacent to each other, there is some protection against such environmental correlations. Nevertheless, any environmental correlations that do exist may increase the covariance among family members. Therefore, estimates of genetic parameters should be treated with some degree of care.

General combining ability (GCA) effects of the parents and specific combining ability (SCA) effects for all biparental combinations were obtained by applying the method of best linear unbiased prediction (BLUP). The mating design model is an incomplete diallel without reciprocals where:

$\mathrm{Y}_{\mathrm{ijk}}=\mu+\mathrm{g}_{\mathrm{j}}+\mathrm{g}_{\mathrm{k}}+\mathrm{s}_{\mathrm{jk}}+\mathrm{e}_{\mathrm{ijk}}$ and $Y_{i j k}$ is the phenotypic observation for the $i$ th progeny member of the family $j k$; $\mu$ is the population mean;

$\mathrm{g}_{\mathrm{j}}$ is the random variable associated with the GCA of the $j$ th female;

$\mathrm{g}_{\mathrm{k}}$ is the random variable associated with the GCA of the $k$ th male;

$\mathrm{s}_{\mathrm{jk}}$ is the random variable associated with the SCA of the parents $j$ and $k$;

$\mathrm{e}_{\mathrm{ijk}}$ is the random error associated with the $i$ th progeny member of the family $j k$.

Analyses were performed using Giesbrecht's algorithm of restricted maximum likelihood (Huber, 1993). The BLUP theory was developed specifically to analyze diverse and unbalanced performance data from dairy cattle (Henderson, 1963, 1973, 1977a, 1977b). The BLUP theory has successfully been adapted to predict future performance of par- ents in forest tree breeding (White and Hodge, 1988). Forest tree breeding shares many of the experimental design problems found in apple breeding. The Wilk-Shapiro test was undertaken to test the normality of the data for each family (Proc. Univariate; SAS, 1990).

\section{Results and Discussion}

All the individual families showed continuous distribution around the midparent with
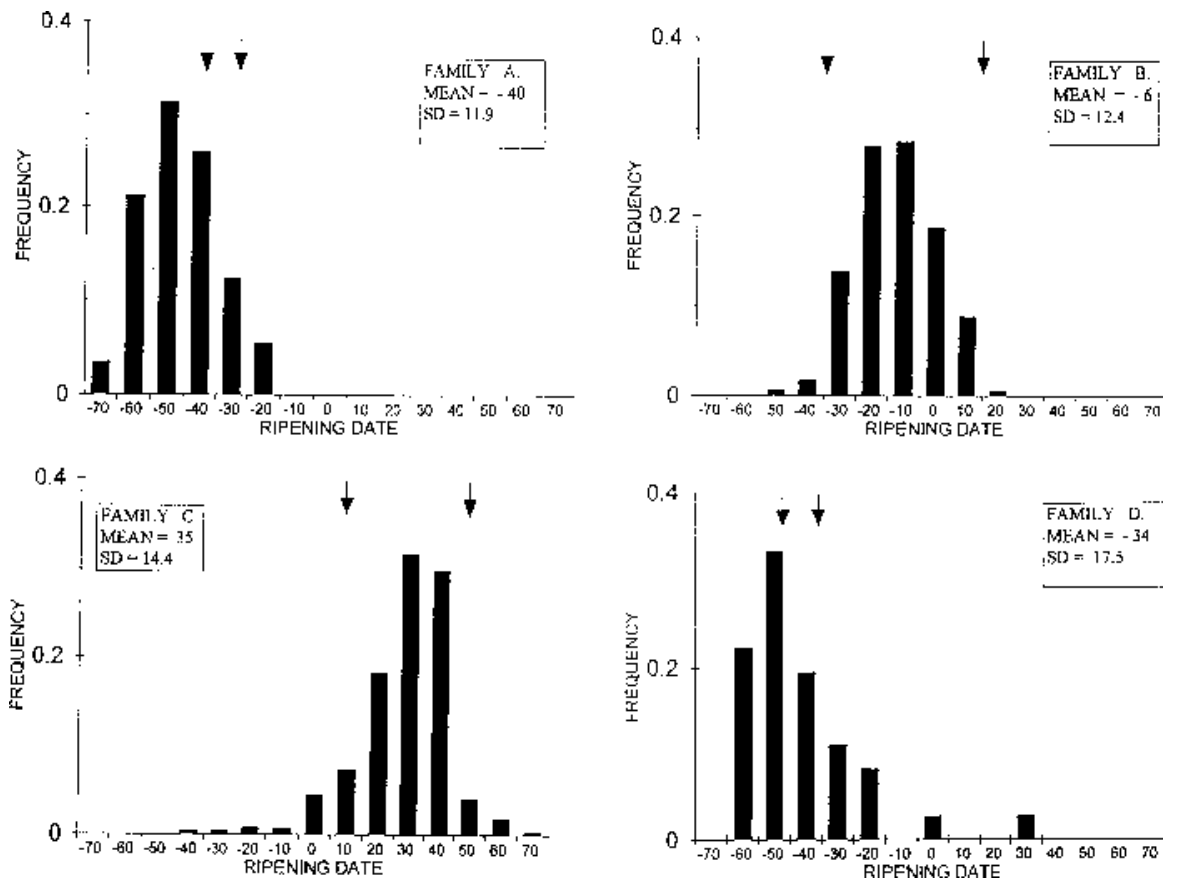

Fig. 1. Frequency distributions of ripening date in four families of apple seedlings: (A) 'William's Favourite' x 'Early McIntosh', (B) 'William's Favourite' x 'Golden Delicious', (C) 'Delicious' x 'Granny Smith', and (D) 'Milton' $x$ 'Carrington Red'. Only families (A) and (B) have normal distributions. Arrows indicate parent cultivar ripening dates. Ripening date expressed as days relative to 'Jonathan'.

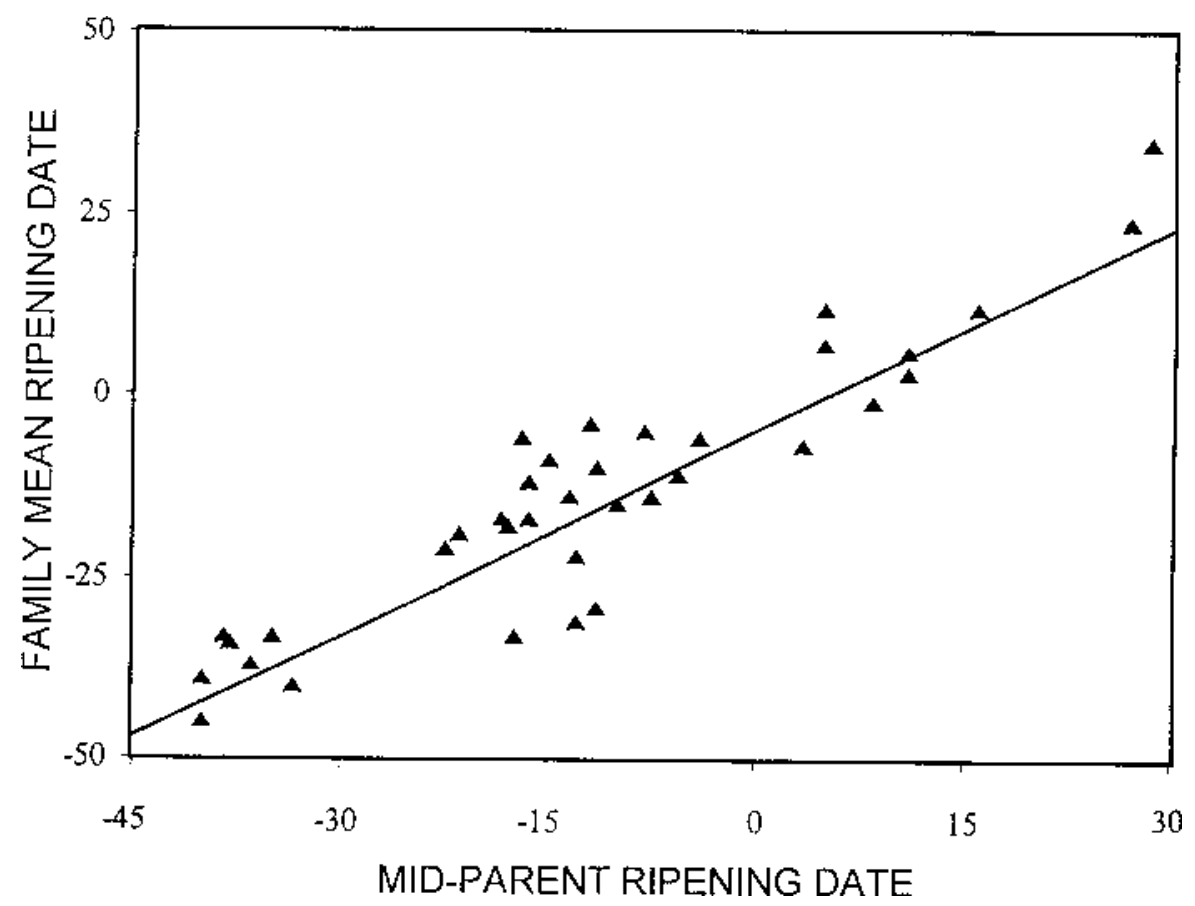

Fig. 2. Offspring midparent regressions of ripening date for 36 apple families. Ripening date expressed as days relative to 'Jonathan'. Regression equation: $y=0.94 x-2.4$. 
earlier than the average midparent harvest date. These average harvest dates are only slightly earlier than the midparent dates, which contrasts with the 2 weeks earlier reported by Brown (1960). The sample variation of all progeny was 438.7 , and of all midparents, accounting for family size, it was 175.3.

Brown (1960) found that families from two late-ripening parents produced only a small proportion of their progeny as late ripening, a phenomenon we did not observe, possibly because only a few of these types of crosses were made in the Stanthorpe program. Brown (1975) proposed a minimum ripening date that was fixed by a minimum fruit development period after bloom. He used this relationship to explain why crosses between two early ripening parents would produce a population skewed toward lateness and with reduced variation. This result was absent with our early $x$ early families, possibly because this theoretical limit of earliness was not yet reached.

Narrow-sense heritability $\left(\mathrm{h}^{2}\right)$ for harvest date was $0.94 \pm 0.067$ (Fig. 2), a relatively high value for a quantitative character, but consistent with the high estimates found for harvest date of Japanese pear (Pyrus pyrifolia Nakai) (Abe et al., 1993), sweet cherry (Prunus avium L.) (Hansche et al., 1966; Hansche and Brooks, 1965), peach (Prunus persica L. Batsch) (Hansche et al., 1972b), and walnut (Juglans regia L.) (Hansche et al., 1972a). Regression of Brown's (1960) apple cultivar progeny means on midparent values reveals that, in his data set, $\mathrm{h}^{2}$ was $0.69 \pm 0.071$.

Heritability, as we have measured it, can be overestimated if basic assumptions are violated. These commonly include the existence of dominance or epistatic genetic components or prior inbreeding within the parents (Falconer, 1989; Fernandez and Miller, 1985). The former is assumed to be low and the latter is known to be negligible amongst our parents. If significant genotype $\times$ environment $(\mathrm{G} \times \mathrm{E})$ interaction exists, then maturity re-ranking will occur in different environments and years. Ignoring this $\mathrm{G} \times \mathrm{E}$ interaction will also cause $\mathrm{h}^{2}$ to be overestimated. This hazard can be avoided by growing parents and offspring in different environments (Casler, 1982; Fernandez and Miller, 1985). This was the case in our experiments, where the parents were grown in a repository under better horticultural conditions than the progeny. Also, the year effects on progeny were reduced by adjusting for season, then averaging across years. Alternatively, if the variation differs between parents and offspring, then the regression can be done on standardized data (Frey and Horner, 1957). This procedure gave an estimate of heritability of $0.924 \pm 0.065$, which is not different from that based on the year-adjusted data.

The high narrow-sense heritability we found for harvest date implies that additive gene effects are predominantly controlling inheritance. This finding is supported by the BLUP analysis where the variance component of GCA (237.8) was nearly 10 times the variance component of SCA (25.4). The GCA estimates (Table 2) can be used to predict the
Table 2. General combining ability (GCA) for ripening date of 13 apple cultivars used as parents.

\begin{tabular}{lr}
\hline Parental cultivar & $\mathrm{GCA}^{\mathrm{z}}$ \\
\hline Stark's Earliest & -16.13 \\
Milton & -11.67 \\
Early McIntosh & -9.27 \\
Canterbury & -12.96 \\
Ruby Gem & -0.21 \\
Carrington Red & -6.69 \\
William's Favourite & -9.62 \\
Stark Earliblaze & -11.00 \\
Jonathan & 8.29 \\
Sayers & 3.98 \\
Delicious & 13.83 \\
Golden Delicious & 14.66 \\
Granny Smith & 36.78 \\
\hline
\end{tabular}

${ }^{\mathrm{z}} \mathrm{GCA}$ expressed as ripening date relative to 'Jonathan'.

progeny mean of future crosses within the parental set. The rank order of parent ripening date and parent GCA is similar when these two variables are regressed, $r^{2}=0.91$.

The SCA effects of each cross (Table 3) indicate deviations from the expected progeny means as predicted by GCA. They have no use outside of the actual crosses from which they were measured, but their small size in relation to GCA effects supports the strong influence of additive genetic effects on the inheritance of maturity.

A knowledge of heritability and combining ability estimates can be useful when planning crosses for a specific ripening period; it can also be used to predict average ripening dates of crosses made for other objectives. Despite variable distributions within families, the best strategy for producing a population of early maturing apple seedlings is to cross cultivars that have an early midparent ripening date. A knowledge of the inheritance of fruit quality characteristics can then be applied to predict the range of fruit quality that will exist within families.

\section{Literature Cited}

Abe, K., Y. Sato, T. Saito, A. Kurihara, and K. Kotobuki. 1993. Inheritance of ripening time of fruit of Japanese pear (Pyrus pyrifolia Nakai). Jpn. J. Breeding 43:289-298.

Bishop, C.J. 1951. A study of the male parental influence in crosses with the Northern Spy apple. Proc. Amer. Soc. Hort. Sci. 57:165-168.

Bohern, B.B., H.E. McKean, and Y. Yamada. 1961. Relative efficiencies of heritability estimates based on regression of offspring on parent. Biometrics 17:481-491.

Brown, A.G. 1960. The inheritance of shape, size and season of ripening in progenies of the cultivated apple. Euphytica 9:327-337.

Brown, A.G. 1975. Apples, p. 3-37. In: J. Janick and J.N. Moore (eds.). Advances in fruit breeding. Purdue Univ. Press, West Lafayette, Ind.

Brown, S.K. 1992. Genetics of apple, p. 333-366. In: J. Janick (ed.). Plant breeding reviews. vol. 9. Wiley, New York.

Casler, M.D. 1982. Genotype $\times$ environment interaction bias to parent-offspring regression heritability estimates. Crop Sci. 22:540-542.

Crane, M.B. and W.J.C. Lawrence. 1933. Genetical studies in cultivated apples. J. Genet. 28:265298.

Davis, M.B., D.S. Blair, and L.P.S. Spangelo. 1954. Apple breeding at the central experimental farm,
Table 3. Specific combining abilities (SCA) of 36 apple crosses for ripening date. Ripening date expressed as days relative to 'Jonathan'.

\begin{tabular}{|c|c|}
\hline$\overline{\text { Cross }}$ & $\mathrm{SCA}^{2}$ \\
\hline Milton x Early McIntosh & -5.70 \\
\hline Milton x Ruby Gem & -2.81 \\
\hline Milton $\times$ Carrington Red & 1.48 \\
\hline Milton $x$ Williams Favourite & 1.62 \\
\hline Early McIntosh x Milton & -0.16 \\
\hline Early McIntosh x Carrington Red & 0.07 \\
\hline Early McIntosh x Sayers & 7.22 \\
\hline William's Favourite x Early McIntosh & -3.08 \\
\hline William's Favourite $x$ Sayers & -3.31 \\
\hline William's Favourite x Golden Delicious & 5.5 \\
\hline Jonathan X Stark's Earliest & 4.2 \\
\hline Jonathan $x$ Milton & 1.47 \\
\hline Jonathan x Early McIntosh & 1.6 \\
\hline Jonathan $\times$ Canterbury & 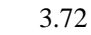 \\
\hline Jonathan $\times$ Ruby Gem & 3.1 \\
\hline Jonathan $\times$ Carrington Red & 0.95 \\
\hline Jonathan $\times$ Stark Earliblaze & -10.8 \\
\hline Jonathan $\times$ Sayers & -2.2 \\
\hline Jonathan $\times$ Golden Delicious & -1.5 \\
\hline Delicious X Stark's Earliest & -5.93 \\
\hline Delicious $\mathrm{x}$ Milton & 2.85 \\
\hline Delicious x Early McIntosh & -1.2 \\
\hline Delicious $x$ Canterbury & -5.1 \\
\hline Delicious x Ruby Gem & -0.3 \\
\hline Delicious $\times$ Carrington Red & 0.2 \\
\hline Delicious X William's Favourite & -1.83 \\
\hline Delicious $\times$ Stark Earliblaze & 9.6 \\
\hline Delicious $\mathrm{x}$ Jonathan & 2.4 \\
\hline Delicious $\times$ Sayers & -1.5 \\
\hline Delicious x Golden Delicious & 0.6 \\
\hline Delicious x Granny Smith & 1.6 \\
\hline Golden Delicious x Early McIntosh & -1.5 \\
\hline Golden Delicious x Carrington Red & -1.5 \\
\hline Golden Delicious $x$ Jonathan & 0.0 \\
\hline Granny Smith x Early McIntosh & 1.92 \\
\hline Granny Smith x Sayers & 0.3 \\
\hline
\end{tabular}

${ }^{2}$ SCA expressed as ripening date relative to 'Jonathan'.

Ottawa, Canada. Proc. Amer. Soc. Hort. Sci. 63:243-250.

Dicenta, F., J.E. Garcia, and E.A. Carbonell. 1993. Heritability of fruit characters in almond. J. Hort. Sci. 68:121-126.

Falconer, D.S. 1989. Introduction to quantitative genetics. 3rd ed. Longman Scientific and Technical, Essex, England.

Fernandez, G.C.J. and J.C. Miller, Jr. 1985. Estimation of heritability by parent-offspring regression. Theor. Appl. Genet. 70:650-654.

Frey, K.J. and T. Horner. 1957. Heritability in standard units. Agron. J. 49:59-62.

Hansche, P.E., V. Beres, and R.M. Brooks. 1966. Heritability and genetic correlation in the sweet cherry. Proc. Amer. Soc. Hort. Sci. 88:173-183.

Hansche, P.E., V. Beres, and H.I. Forde. 1972a Estimates of quantitative genetic properties of walnut and their implications for cultivar improvement. J. Amer. Soc. Hort. Sci. 97:279285.

Hansche, P.E. and R.M. Brooks. 1965. Temporal and spatial repeatabilities of a series of quantitative characters in sweet cherry (Prunus avium). Proc. Amer. Soc. Hort. Sci. 88:173-183.

Hansche, P.E., C.O. Hesse, and V. Beres. 1972b. Estimates of genetic and environmental effects on several traits in peach. J. Amer. Soc. Hort. Sci. 97:76-79.

Hartman, F.O. and F.S. Howlett. 1942. An analysis of the fruit characteristics of seedlings of Rome Beauty, Gallia Beauty and Golden Delicious parentage. Proc. Amer. Soc. Hort. Sci. 40:241244.

Henderson, C.R. 1963. Selection index and ex- 


\section{Breeding, Cultivars, Rootstocks, \& Germplasm Resources}

pected genetic advance, p. 141-163. In: W.D. Hanson and H.F. Robinson (eds.). Statistical genetics and plant breeding. NAS-NCR Publ. 982, Washington, D.C.

Henderson, C.R. 1973. Sire evaluation and genetic trends, p. 10-41. In: Animal Breeding and Genet. Symp. in Honour of J. Lush. Animal Sci. Assn. Amer., Champaign, Ill.

Henderson, C.R. 1977a. Best linear unbiased prediction of breeding values not in the model for records. J. Dairy Sci. 60:783-787.

Henderson, C.R. 1977b. Prediction of future records, p. 615-38. In: E. Pollak, O. Kempthorne, and T.B. Bailey (eds.). Proc. Intl. Conf. Quantitative Genetics. Iowa State Univ. Press, Ames.
Howlett, F.S. and J.H. Gourley. 1946. Characteristics of the progeny obtained from utilizing standard commercial varieties in apple breeding. Proc. Amer. Soc. Hort. Sci. 48:121132.

Huber, D. 1993. Optimal mating designs and optimal techniques for analysis of quantitative traits in forest genetics. PhD Diss., Univ. of Florida, Gainesville.

Kempthorne, O. and O.B. Tandon. 1953. The estimation of heritability by regression of offspring on parent. Biometrics 9:90-100.

SAS Institute. 1990. SAS procedures guide. Version 6, 3rd ed. SAS Inst.. Cary, N.C.

Tancred, S.J., A.G. Zeppa, and J.N. Cummins. 1994.
Thirty-seven apple varieties of Australian origin. Fruit Var. J. 48:118-125.

Thompson, T.E. and J.F. Baker. 1993. Heritability and phenotypic correlations of six pecan nut characteristics. J. Amer. Soc. Hort. Sci. 118:415418.

Way, R.D., et al. 1990. Apples, p. 3-62. In: J.N. Moore and J.R. Ballington, Jr. (eds.). Genetic resources of temperate fruit and nut crops. Acta Hort. 290. Intl. Soc. Hort. Sci., Wageningen, The Netherlands.

White, T.L. and G.R. Hodge. 1988. Best linear prediction of breeding values in a forest tree improvement program. Theor. Appl. Genet. 76:719-727. 